\title{
Isolation and molecular characterization of herpesvirus from cultured European eels Anguilla anguilla in Taiwan
}

\author{
Pen Heng Chang ${ }^{1, *}$, Yie Hour Pan ${ }^{1}$, Chein Ming Wu ${ }^{2}$, Shu Ting Kuo ${ }^{3}$, \\ Huu Yun Chung ${ }^{4}$
}

${ }^{1}$ Department of Veterinary Medicine, College of Agriculture, National Taiwan University, Taipei, Taiwan, ROC

${ }^{2}$ Tau-Yang Livestock Disease Control Center, Tauyang, Taiwan, ROC

${ }^{3}$ National Institute for Animal Health, Tansui, Taiwan, ROC

\begin{abstract}
A herpesvirus has been isolated for the first time from a population of European eels Anguilla anguilla cultured in a recirculated system in Taiwan. Syncytia formation was detected in EP-1 (eel epidermis) cell cultures inoculated with cell-free homogenates prepared from both integument and visceral organs of moribund fish. Inoculation of homogenates onto EK (eel kidney) cell cultures induced giant cell formation. Subsequent passages produced a consistent and progressive cytopathic effect (CPE) in cell cultures. In this study, EP-1 cell cultures infected with EEHV (European eel herpesvirus) were examined using an electron microscope. Numerous nucleocapsids of about $100 \mathrm{~nm}$ in diameter were found within the nucleus of infected cells, whereas enveloped particles were observed within the cytoplasm. The mature viral particle, about $235 \mathrm{~nm}$ in diameter, had an electrondense core with a hexagonal nucleocapsid surrounded by a coarse capsule. Histopathological examination of moribund fish showed epithelial hyperplasia with intracytoplasmic metabolic inclusions in the skin. Macrophage aggregates were found in liver, spleen, and kidney. A pair of primers designed from channel catfish virus and salmonid herpesvirus 1 was used in a polymerase chain reaction. A $402 \mathrm{bp}$ fragment was amplified and cloned from genomic DNA of EEHV. The nucleotide homology was $99 \%$ (298 of 300) with DNA polymerase of eel herpesvirus (anguillid herpesvirus). EEHV nucleic acids were detected within melanomacrophages in the skin, liver, spleen and kidney by in situ hybridization (ISH).
\end{abstract}

KEY WORDS: Virus isolation - Molecular characterization - In situ hybridization - Herpesvirus . European eel $\cdot$ Anguilla anguilla

\section{INTRODUCTION}

Herpesviruses are the most commonly encountered DNA viruses in teleost fish (Hedrick et al. 1990). Most of the herpesviruses are associated with hyperplastic growths or neoplasms of the integument (Hedrick \& Sano 1989), although few of these viruses have been associated with serious clinical diseases and mortality (Wolf 1988). Proliferative conditions of the epidermis caused by herpesvirus have been reported in turbot

*E-mail: penheng@cc.ntu.edu.tw
Scophthalmus maximus, walleye pike Stizostedion vitreum vitreum, lake trout Salvelinus namaycush, northern pike Esox lucius, salmon masou Oncorhynchus masou, golden ide Leuciscus idus, koi carp Cyprinus carpio, and eel Anguilla japonica (McAllister et al. 1985, Bradley et al. 1989, McAllister \& Herman 1989, Hedrick et al. 1990, Ueno et al. 1992, McAllister 1993, Shih et al. 1993). Systemic diseases caused by herpesviruses occur in channel catfish Ictalurus punctatus (Thune 1993) and goldfish Carassius auratus (L.) (Jung \& Miyazaki 1995).

Because the European eel Anguilla anguilla is an important commercial species in Taiwan, the fish has 
been cultured in recirculated systems to increase production. The present paper describes the first isolation of a herpesvirus from European eels cultured in recirculated systems in Taiwan. The relationships between fish mortality, virus, and other microorganisms isolated from moribund fish are discussed. Also, the molecular characterization of the herpesvirus is presented.

\section{MATERIALS AND METHODS}

Fish. European eels, 150 to $200 \mathrm{~g}$ in weight, were collected from a commercial farm in northern Taiwan in which increasing mortality had been observed. The eels were cultured in a recirculated system with a water temperature of $26^{\circ} \mathrm{C}$. The eels were subjected to standard necropsy procedures, which included examinations for both external and internal pathogens (Amos 1985). Bacterial isolation was performed on tissues of the liver, spleen, kidney and heart by inoculating onto Trypticase Soya Agar (TSA, Difco) plates and incubated at $30^{\circ} \mathrm{C}$ for $24 \mathrm{~h}$. Parasite examination was performed by wet-mount examination of the gills of all moribund fish.

Virus isolation and propagation. The integument and visceral organs including liver, spleen, heart, head kidney and trunk kidney of 5 moribund fish were collected separately for virus isolation. Samples of integument and visceral organs were pooled and homogenized in phosphate-buffered saline (PBS) to give a $10 \%(\mathrm{w} / \mathrm{v})$ suspension, and were then centrifuged at $3000 \times g$ for $20 \mathrm{~min}$ at $4^{\circ} \mathrm{C}$. The supernatant was filtered through a $0.45 \mu \mathrm{m}$-pore filter. Two cell lines, EP1 (eel epidermis) (Chen et al. 1982) and EK (eel kidney) (Kou et al. 1995), were used for virus isolation. The cell cultures were grown in L15 medium containing 10\% fetal calf serum with $100 \mathrm{IU} \mathrm{ml}^{-1}$ penicillin and $100 \mu \mathrm{g}$ $\mathrm{ml}^{-1}$ streptomycin. Monolayers of the cells were grown in 24-well tissue-culture plates and inoculated with $0.1 \mathrm{ml}^{-1}$ well of a 10 -fold serial dilution of the filtrated homogenate. The cell cultures were incubated at $28^{\circ} \mathrm{C}$ for $14 \mathrm{~d}$, examined daily for a CPE. When a CPE was observed, a $0.1 \mathrm{ml}$ aliquot of culture fluid was inoculated into a $25 \mathrm{~cm}^{2}$ flask of EP-1 cell cultures. Cell culture medium was obtained from the second subcultures and stored at $-70^{\circ} \mathrm{C}$.

Histopathology. Histopathologic examination of the collected fish was performed. Samples of the integument and visceral organs were fixed in $10 \%$ neutral formalin, embedded in paraffin, sectioned at $5 \mu \mathrm{m}$, and stained with Mayer's hematoxylin and eosin.

Thin-section electron microscopy. EP-1 cell cultures in a $25 \mathrm{~cm}^{2}$ flask were inoculated with $10^{3.5} \mathrm{TCID}_{50}$ of EEHV and then incubated at $28^{\circ} \mathrm{C}$. The cells were harvested by flushing them from the flask into the medium at $60 \mathrm{~h}$ post-inoculation. The medium was adjusted to $1 \times 10^{7}$ cells ml ${ }^{-1}$, collected in a sterile Eppendorf flask and centrifuged at $1500 \times g$ for $10 \mathrm{~min}$ at $4{ }^{\circ} \mathrm{C}$. The supernatant was discarded and $1 \mathrm{ml}$ of $2.5 \%$ glutaraldehyde (0.1 M cacodylate buffer, $\mathrm{pH}$ 7.2) was added carefully to the pellet and fixed for $2 \mathrm{~h}$ at $4^{\circ} \mathrm{C}$. The pellet was gently removed from the bottom of the Eppendorf flask and allowed to fix for another $4 \mathrm{~h}$. The pellet was then rinsed and equilibrated 3 times (10 min each) with $0.1 \mathrm{M}$ cacodylate buffer, $\mathrm{pH} 7.2 ; 1 \%$ osmium tetroxide ( $0.1 \mathrm{M}$ cacodylate buffer, $\mathrm{pH} 7.2)$ was then added carefully to the pellet, which was kept at room temperature for $2 \mathrm{~h}$. The pellet was then rinsed and equilibrated 3 times (10 min each) by $0.1 \mathrm{M}$ cacodylate buffer, $\mathrm{pH} 7.2$, and subsequently dehydrated using an ethanol series $(35,50,70,85,90,95,100 \%, 10 \mathrm{~min}$ each). The pellet was then immersed in a series of ethanol-resin mixtures ( $2 \mathrm{~h}$ each). The ratios of ethanol to resin were $3: 1,1: 1$, and 1:3. Embedment was achieved by $100 \%$ resin immersion. The sample was then polymerized for $24 \mathrm{~h}$ at $70^{\circ} \mathrm{C}$. Thick sections were stained with $1 \%$ toluidine blue solution and observed under a light microscope to determine the cell morphology. Ultrathin sections $(0.35 \mu \mathrm{m})$ were doublestained with $1 \%$ uranyl acetate and lead citrate and examined by transmission electron microscope (Joel JEM 1200 EX II).

PCR analysis, cloning and DNA sequence analysis. Chromosomal DNA of moribund fish collected from the farm was prepared following the method described by Than \& Moon (1996). The DNA was amplified by PCR with a pair of primers designed from the sequence encoded to DNA polymerase of channel catfish virus and salmonid herpesvirus 1 (Davison 1992, 1998). The sequences of the pair of primers were $\mathrm{F} 1=$ 5'-ACATTTGCGCGACCATCCTC-3' and R1 = 5'CGGTCTCATCGCAGGGTCTC-3'. A $100 \mu \mathrm{l}$ reaction mixture was prepared with $10 \mu \mathrm{l}$ of $10 \times$ PCR buffer (10 mM Tris-HCl pH 8.3, $50 \mathrm{mM} \mathrm{KCl}, 1.5 \mathrm{mM} \mathrm{MgCl}_{2}$, $0.01 \%$ gelatin), $100 \mathrm{mM}$ of each of the deoxyribonucleosides, $1 \mathrm{mM}$ of each primer, $10 \mu \mathrm{l}$ of purified DNA, $2 \mathrm{U}$ of Taq polymerase, and made up to volume with sterile distilled water. PCR amplification was performed in a thermocycler (PTC-100) by 35 cycles of $1 \mathrm{~min}$ of denaturation at $94^{\circ} \mathrm{C}, 1 \mathrm{~min}$ of annealing at $60^{\circ} \mathrm{C}$, and $1 \mathrm{~min}$ of extension at $72^{\circ} \mathrm{C}$, followed by incubation for $5 \mathrm{~min}$ at $72^{\circ} \mathrm{C}$. Using a $6 \times$ loading buffer $(2 \mu \mathrm{l})$, the PCR products $(10 \mu \mathrm{l})$ were loaded horizontally onto a $2 \%$ agarose gel and subjected to electrophoresis for $40 \mathrm{~min}$ at $50 \mathrm{~V}$ in $0.5 \times$ TBE buffer. Gels were stained with ethidium bromide, and photographed under UV-light transillumination. A 100 bp DNA ladder was included as a molecular weight standard on each gel. Fragments derived from PCR product on the gel were retrived through gel purification and applied to PCR II-TOPO TA vector for 
DNA cloning. Direct sequencing of the cloned gene was carried out using ABI PRISM 377-96 Sequencer (Perkin-Elmer) according to the manufacturer's instructions. Analyses were carried out using the BLAST (basic local alignment search tool) search programs developed at NCBI (National Center for Biotechnology Information, www.ncbi.nlm.nih.gov/BLAST/).

Probe. A 288 bp DNA polymerase of EEHV was used as a probe. The sequences were P1 $=5^{\prime}$-CTACACAAGAGTGTGGAGAC-3' and P2 = 5'-AAATCACAGTCATGCCGGGA-3'. The DNA probe was synthesized by the PCR technique using DIG-labeled dNTP mixtures instead of radiolabeled probes. The EEHVspecific probe was electrophoresed in a $0.8 \%$ horizontal agarose gel and its specificity examined by southern hybridization. The results showed that the DIG-labeled $288 \mathrm{bp}$ fragment could be used as an EEHV-specific probe for ISH using $50 \%$ formamide. The concentration of the labeled probe was determined using a Pharmacia biotech GeneQuant II DNA/RNA calculator (Young 1992).

In situ hybridization. Formalin-fixed, paraffinembedded tissues collected from naturally infected eels were used in the experiment. Sections of $5 \mu \mathrm{m}$ thickness were deparaffinized and rehydrated by standard procedures and digested with $20 \mu \mathrm{g} \mathrm{ml}^{-1}$ of proteinase $\mathrm{K}$ for $15 \mathrm{~min}$ at $37^{\circ} \mathrm{C}$. The slides were treated with $500 \mu \mathrm{l}$ per slide of prehybridization buffer for $1 \mathrm{~h}$ at $37^{\circ} \mathrm{C}$, overlaid with $500 \mu \mathrm{l}$ per slide of hybridization buffer, and incubated at $90^{\circ} \mathrm{C}$ for $10 \mathrm{~min}$. They were then transferred to $37^{\circ} \mathrm{C}$ and hybridized overnight. After hybridization, the slides were washed with decreasing concentrations of saline-sodium citrate (SSC), followed by washing and blocking, and reacted with anti-DIG Ab. The slides were washed with maleic acid buffer and immersed in buffer solution for visualization.

Detection of hybridization signals. The slides were visualized by Fast Red TR (FR-TR) substrate reaction. Slides were buffered in TM buffer solution (200 mM Tris-HCl, $10 \mathrm{mM} \mathrm{NaCl}, \mathrm{pH}$ 8.5) for $2 \mathrm{~min}$. The FR-TR substrate reaction buffer was prepared by dissolving $1 \mathrm{mg}$ of naphthol-AS-MX phosphate in $250 \mu \mathrm{l}$ TM buffer and $5 \mathrm{mg}$ of Fast Red TR salt (Sigma) in $750 \mu \mathrm{l}$ TM buffer separately. The 2 solutions were mixed and brought to $4 \mathrm{ml}$ with TM buffer. Levamisole was added to a final concentration of $5 \mathrm{mM} \mathrm{ml}^{-1}$ for histological sections. The slides were overlaid with $300 \mu$ per slide of the FR-TR substrate reaction buffer and left to react in the dark for $15 \mathrm{~min}$. After the reaction the slides were washed 2 to 3 times with PBS (Speel et al. 1994). The slides were then air-dried and sealed with Permount and examined either under a light microscope or a fluorescent microscope equipped with a $550 \mathrm{~nm}$ wavelength filter.

\section{RESULTS}

\section{External symptoms of disease}

External symptoms varied among moribund individuals. Most had pale gills and excessive mucus secretion on the body surface. The internal visceral organs appeared normal. Only a few fish displayed bloody congestion of the anal fin, reddening of the anal and urogenital regions, and petechial hemorrhages on the abdominal surface. Generally, the gills were pale and swollen, and excessive mucus production was observed on the gills as well as the body surface. Cumulative mortality was about $30 \%$.

\section{Bacteriological and parasitological results}

Edwardsiella tarda was isolated from the liver, spleen and kidney of some (but not all) fish, and Pseudodactylogyrus spp. was observed in the gills of all moribund fish during wet-mount examination.

\section{Virus isolation}

Syncytial formation was detected in EP-1 cell cultures after incubation with homogenates prepared from both the integument and visceral organs of moribund fish. Subsequent passages produced consistent and progressive CPE on EP-1 cell cultures within 3 to 7 days post injection (dpi) (Fig. 1A). Inoculation of homogenates into EK cell cultures resulted in development of a CPE within 3 dpi (Fig. 1B), and giant cell formation within 5 to 10 dpi (Fig. 1C).

\section{Negative-contrast electron microscope observations}

Hexagonal capsids surrounding nucleoprotein cores of varying density were observed in the nucleus and throughout the cytoplasm of EP-1 cells (Fig. 2A). The nuclear membranes remained largely intact, but cytoplasmic changes were evident. Nucleocapsids measuring about $100 \mathrm{~nm}$ in diameter were found within nucleus. Enveloped particles were observed within the cytoplasm, some of them in the vacuoles. The mature viral particle was about $235 \mathrm{~nm}$ in diameter (Fig. 2, lower right).

\section{Histopathology}

Histological examination of moribund fish indicated that the integument is the primary target tissue. 

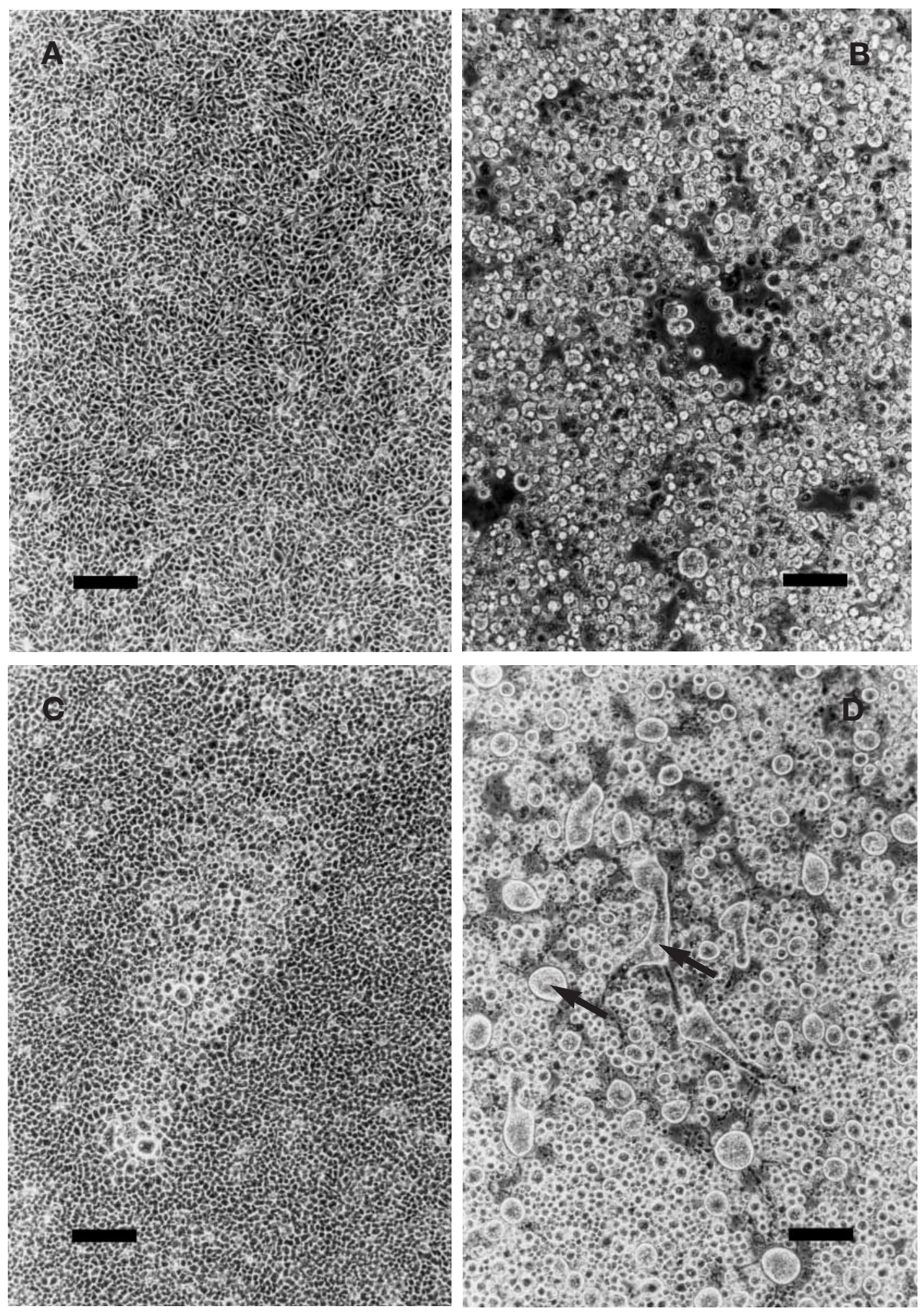

Fig. 1. Anguilla anguilla. Photomicrographs of cell cultures. (A) Uninfected control cultures showing normal EP-1 (eel epidermis) cellular morphology; (B) EP-1 cell culture infected with European eel herpesvirus on Day 4 post-infection showing syncytial formation; (C) EK (eel kidney) cell culture infected with European eel herpesvirus on Day 3 post-infection showing cytopathic effects; (D) EK cell culture infected with European eel herpesvirus on Day 5 post-infection showing giant cell formation (arrows). Scale bars in (A) and $(C)=100 \mu \mathrm{m}$, in (B) and (D) $=25 \mu \mathrm{m}$ 

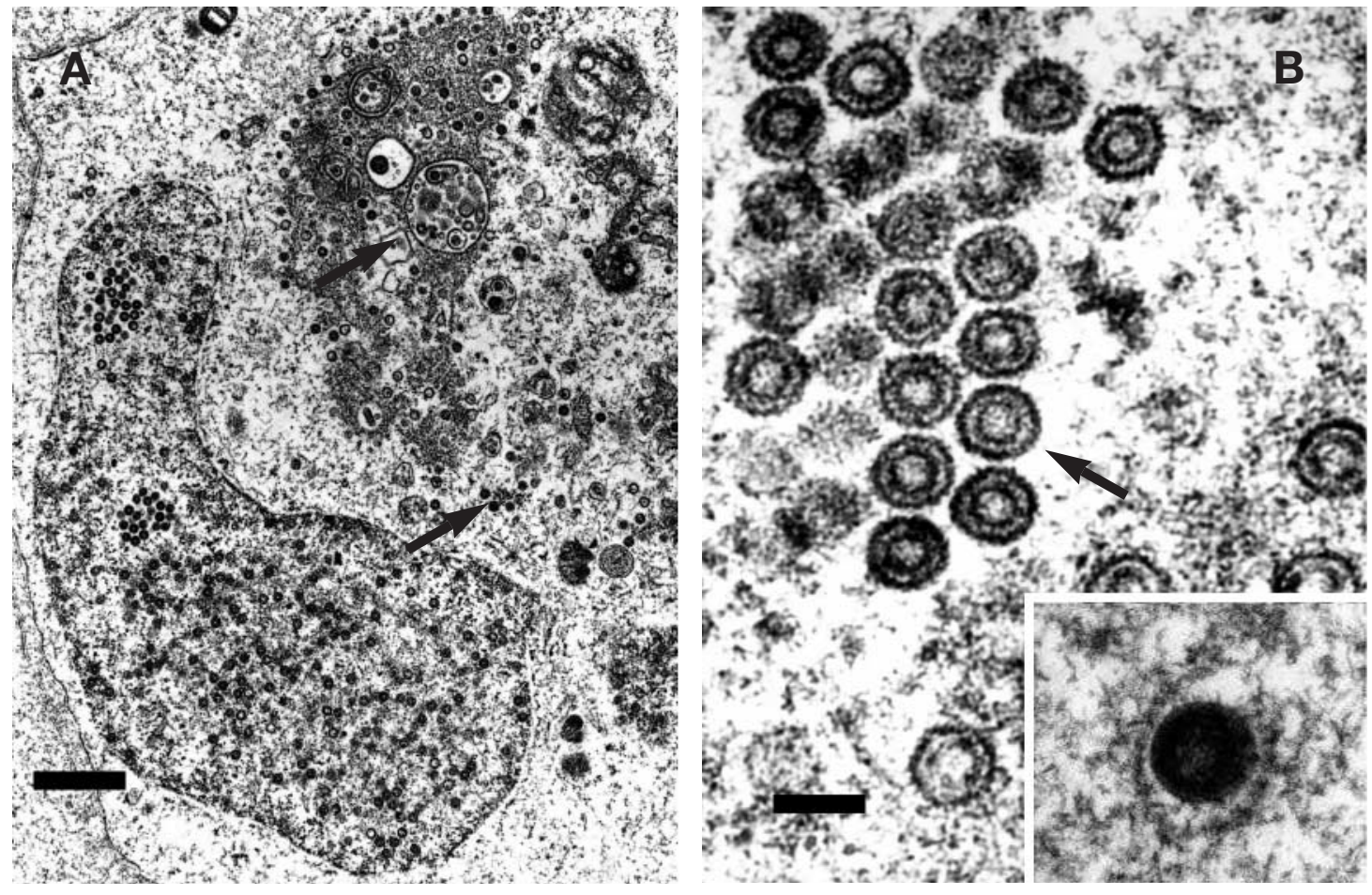

Fig. 2. Anguilla anguilla. Transmission electron micrographs of EP-1 cell infected with European eel herpesvirus. (A) Viral particles replicated in the nucleus (arrows) and released into the cytoplasm (arrow); scale bar = $1 \mathrm{~mm}$. (B) Enveloped virions in the cytoplasm (arrow) and nucleocapsids in the nucleus (inset); scale bar $=250 \mu \mathrm{m}$

Integumentary lesions were characterized by multifocal to diffuse epithelial hyperplasia with intracytoplasmic metabolic inclusions (Fig. 3A). Macrophage aggregates were found in the liver, spleen, and kidney (Fig. 3B). The lesions of the gill and visceral organs were in accordance with those of the external lesions. Various numbers of Pseudodactylogyrus spp. were found in the gill lamellae of all fish examined.

\section{PCR analysis, cloning and DNA sequence analysis}

Two fragments (approximately 400 and $600 \mathrm{bp}$ ) were detected by PCR analysis of moribund fish collected from the farm. The $400 \mathrm{bp}$ fragment is the expected size of amplification, and this fragment was cloned and sequenced. A continuous stretch of 402 nucleotides was derived (Fig. 4). The sequence has been submitted to GenBank (Accession number of AF363783). Nucleotide homology was $99 \%$ (298/300) with the DNA polymerase of eel herpesvirus (anguillid herpesvirus).

\section{Detection of EEHV DNA by in situ hybridization}

Distinct positive signals were detected in the skin and viscera of naturally infected eels. Positive cells contained a brown reaction product, mainly in the melanomacrophages and melanomacrophage aggregates (Fig. 5). EEHV-infected cells were detected in the skin, liver, spleen and kidney. Positive signals were also detected in a few inclusions in the skin. No signals were detected in the unprobed sections.

\section{DISCUSSION}

This study reports the first isolation of herpesvirus from diseased European eels cultured in recirculating systems in Taiwan. The nature of the disease outbreak and the results of present laboratory analyses indicated a viral etiology to similar to that the disease in cultured eels. The abundance of EEHV in melanomacrophages of the viscera and skin detected by in situ hybridization suggested that EEHV plays an important role in the infection. Although a bacterial pathogen, Edwardsiella tarda, was noticed in a few samples, no relationship between the presence of the bacteria and the disease outbreak could be found, since histopathological examination revealed no lesions related to E. tarda infection (Miyazaki \& Egusa $1976 a, b)$. However, the outbreak of a disease in which a latent herpesvirus infection is activated may be stress-mediated (Mellergaard \& Bloch 1988). Mortality 

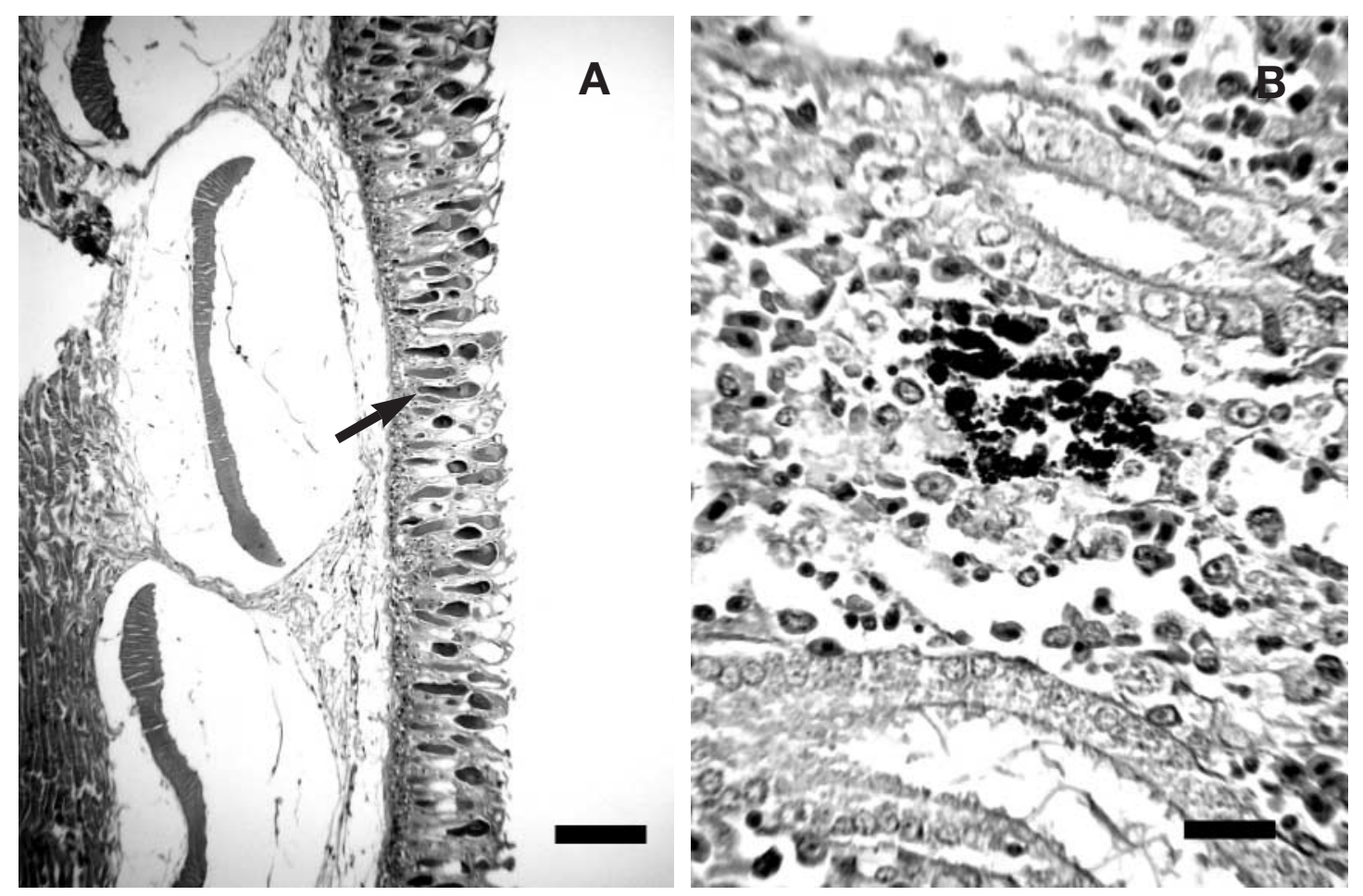

Fig. 3. Anguilla anguilla. Histopathology of natural infected European eel. (A) Diseased fish showing epithelial hyperplasia with metabolic intracytoplasmic inclusions (arrow) in the skin; scale bar $=100 \mu \mathrm{m}$. (B) Diseased fish with macrophage aggregates in the kidney; scale bar $=25 \mu \mathrm{m}$

often occurs after cultural or environmental stress, and the incidence of bacteria also constitutes a systematic stress (McAllister 1993). Thus, mortality is probably not due solely to the virus but is the result of concurrent bacterial infection.

Most herpesviruses detected in fish are associated with non-fatal hyperplasia (Wolf 1988, Hedrick \& Sano 1989). In the disease, outbreak examined in the present study, the epidermal hyperplasia coincided with that described for other herpesvirus-infected fish species except for the appearance of intracytoplasmic metabolic inclusions in our study (McAllister et al. 1985, Bradley et al. 1989, McAllister \& Herman 1989, Hedrick et al. 1991a,b, McAllister 1993, Shih et al. 1993). However, gill filament necrosis related to herpesvirus-infected Japanese eels, Anguilla japonica, has not been found in the disease (Lee et al. 1999).

A virus-induced CPE was evident in EP-1 and EK cell cultures. In the EP-1 cell cultures, the syncytia formed by EEHV infection is typical of CPEs observed with other fish herpesvirus (Fig. 1B); rapid growth of the virus in cell cultures has been reported in WSHV (white sturgeon herpesvirus) infection of WSSK-1 cells (Hedrick et al. 1991a,b). The CPE of giant cell formation in virus-infected EK cells was different: the type of lesion observed in EK cell has also been reported for the herpesvirus infection of the eel (Kobayashi \& Miyazaki 1997). Different types of CPE could be due to differing compatibilities between virus and target cells (Hedrick et al. 1991a,b).

The morphological properties (icosahedral capsids of about $100 \mathrm{~nm}$ in diameter and an enveloped virion of about $235 \mathrm{~nm}$ in diameter) of EEHV support its classifi-

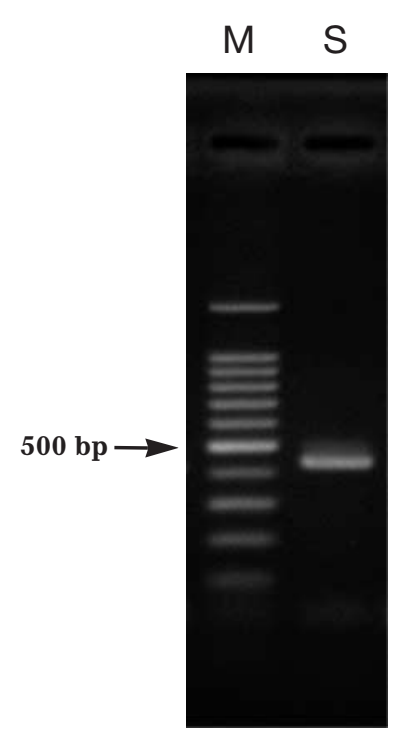

Fig. 4. Anguilla anguilla. Agarose gel electrophoretic analysis of the cloned fragment (approximately 400 $\mathrm{bp}$ ) from PCR product of EEHV obtained with Primers F1 and F2. Lane M: 100 bp DNA; Lane S: sample 

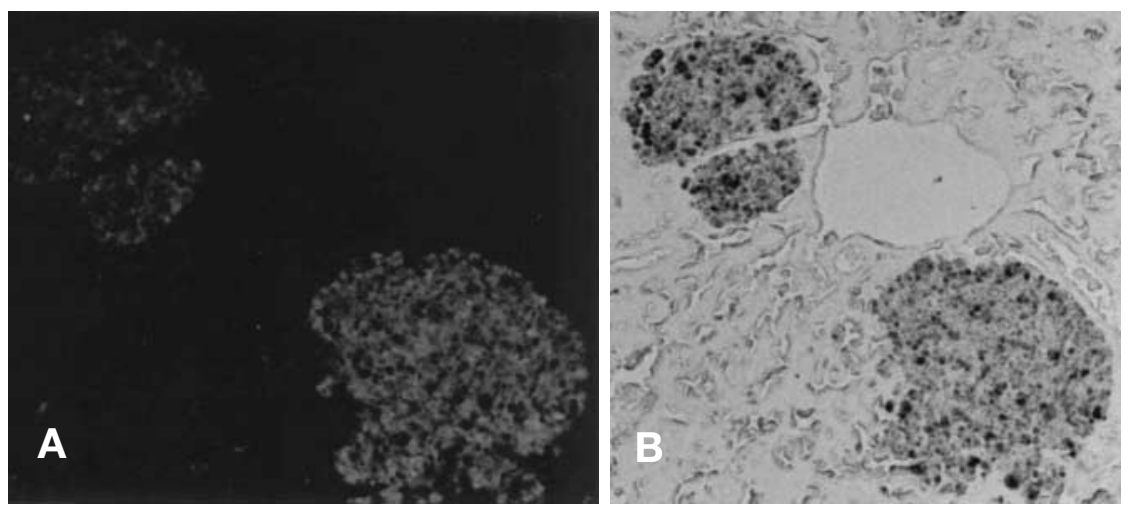

Fig. 5. Anguilla anguilla. In situ hybridization of European eels with natural infection. (A) Strong signals detected throughout the melanomacrophage aggregates in head kidney observed with fluorescent microscope (FR-TR); (B) melanomacrophage aggregates corresponding with location of (A) are black-brown when observed under light microscope (FR-TR). (A) and (B) $=200 \times$ cation as a member in the family Herpesviridae (Roizman 1992). Viral nucleocapsids were composed of a solid high-density core enclosed by a hexagonal shell (Nii 1992). Intranuclear assembly, perinuclear envelopment and syncytia induced in EP-1 cells are features of EEHV which are common to other known herpesviruses (Iida et al. 1991, Nii 1992, Watson et al. 1995).

Gene amplification by PCR was developed for the detection of the EEHV polymerase genes. The DNA gene was amplified with 1 primer set constructed from the sequence encoded with the DNA polymerase sequence of Salmonid herpesvirus 1 and the channel catfish virus (Davison 1992, 1998). Two fragments (approximately 400 and $600 \mathrm{bp}$ ) were amplified from the PCR product, and the $400 \mathrm{bp}$ fragment was collected for cloning and sequencing. A continuous sequence of 402 nucleotides was derived, and the nucleotide homology was $99 \%$ (298 of 300) with the polymerase-related genes of anguillid herpesvirus. Based on these results, herpesvirus infection of European eels was identified.

Further studies on the biochemical and serological relatedness of EEHV to other piscine herpesviruses are also under investigation to determine the diversity among viruses isolated from different piscine species.

Acknowledgements. We thank Professor Chu Fang Lo, Department of Zoology, National Taiwan University, for providing the EP-1 and EK used in the study. Professor Shiow Suey Lai, Department of Veterinary Medicine, National Taiwan University and Ya Li Hsu, Institute of Zoology, Academia Sinica for reviewing the article, and Professor Cheng I Liu, Graduate Institute of Veterinary Pathology, National ChungShing University for helping in the histopathological study. The study was supported by a grant from Council of Agriculture, ROC.

\section{LITERATURE CITED}

Amos K (1985) Procedures for the detection of certain fish pathogens. Fish health section bluebook, American Fisheries Society, Bethesda, MD
Bradley TM, Medina DJ, Chang PW, McClain J (1989) Epizootic epitheliotropic disease of lake trout, Salvelinus namaycush: history and viral etiology. Dis Aquat Org 7: 195-201

Chen SN, Ueno Y, Kou GH (1982) A cell line derived from Japanese eel, Anguilla japonica, kidney. Proc Natl Sci Counc Repub China 6:93-100

Davison AJ (1992) Channel catfish virus: a new type of herpesvirus Virology 186:9-14

Davison AJ (1998) The genome of salmonid herpesvirus. 1. J Virol 72:1974-1982

Hedrick RP, Sano T (1989) Herpesviruses of fishes. In: Ahne W, Kurstak E (eds) Viruses of lower vertebrates. SpringerVerlag, Munich, p 160-171

Hedrick RP, Groff JM, McDowell TS, Wingfield WH (1990) An iridovirus from the integument of white sturgeon. Dis Aquat Org 8:39-44

Hedrick RP, McDowell TS, Groff JM, Yun S, Wingfield WH (1991a) Isolation of an epitheliotropic herpesvirus from white sturgeon Acipenser transmontanus. Dis Aquat Org 11:49-56

Hedrick RP, McDowell TS, Rosemark R, Aronstein D, Lannan CN (1991b) Two cell lines from white sturgeon. Trans Am Fish Soc 120:528-534

Iida Y, Nakai T, Sorimachi M, Masumura K (1991) Histopathology of a herpesvirus infection in larvae of Japanese flounder Paralichthys olivaceus. Dis Aquat Org 10:59-63

Jung SJ, Miyazaki T (1995) Herpesviral haematopoietic necrosis of goldfish, Carassius auratus (L.). J Fish Dis 18: 211-220

Kobayashi T, Miyazaki T (1997) Characterization and pathogenicity of a herpesvirus isolated from cutaneous lesion in Japanese eel, Anguilla japonica. Fish Pathol 32:89-95

Kou G H, Wang CH, Hung HW, Jang YS, Chou CM, Lo CF (1995) A cell line (EP-1 cell line) derived from 'Beko disease' affected Japanese eel elver, Anguilla japonica persistently infected with Pleistophora anguillarum. Aquaculture 132:161-173

Lee NS, Nomura Y, Miyazaki T (1999) Gill lamellar pillar cell necrosis, a new birnavirus disease in Japanese eels. Dis Aquat Org 37:13-21

McAllister PE (1993) Salmonid fish viruses. Cold-water marine fish viruses. In: Stoskopf MK (ed) Fish medicine. WB Saunders, Philadelphia, p 380-408, 697-711

McAllister PE, Herman RL (1989) Epizootic mortality in hatchery-reared lake trout Salvelinus namaycush caused by a putative virus possibly of the herpesvirus group. Dis Aquat Org 6:113-119

McAllister PE, Lidgerding BC, Herman RL, Hoyer LC, Hankins J (1985) Viral diseases of fish: first report of carp pox in 
golden ide (Leuciscus idus) in North America. J Wildl Dis 21:199-204

Mellergaard S, Bloch B (1988) Herpesvirus-like particles in angelfish, Pterophyllum altum. Dis Aquat Org 151-155

Miyazaki T, Egusa S (1976a) Histopathological studies of Edwardsiellosis of the Japanese eel, Anguilla japonica. I. Suppurative interstitial nephritis form. Fish Pathol 11: 33-44

Miyazaki T, Egusa S (1976b) Histopathological studies of edwardsiellosis of the Japanese eel, Anguilla japonica. II. Suppurative hepatitis form. Fish Pathol 11:67-76

Nii S (1992) Electron microscopic study on the development of herpesviruses. J Electron Microsc 41:414-423

Roizman B (1992) The Herpesviridae. In: Francki et al. (ed) classification and nomenclature of viruses. Arch Virol (Suppl) 2:103-110

Shih HH, Lu CC, Chen SN (1993) Eel herpesvirus in Formosa: a herpesvirus from cultured Japanese eels (Anguilla japonica). Rep Fish Dis Res 13:86-96

Editorial responsibility: Jo-Ann Leong,

Corvallis, Oregon, USA
Than KM, Moon CD (1996) Polymerase chain reaction amplification of the thymidine kinase and protein kinase-related genes of channel catfish virus and a putative pilchard herpescirus. J Virol Methods 61:65-72

Thune RL (1993) Catfish viruses. In: Stoskopf MK (ed) Fish medicine. W B Saunders, Philadelphia, p 521-524

Ueno Y, Kitao T, Chen SN, Aoki T, Kou FH (1992) Characterization of a Herpes-like virus isolated from cultured Japanese eels in Taiwan. Fish Pathol 27:7-17

Watson LR, Yun SC, Groff JM, Hedrick RP (1995) Characteristics and pathogenicity of a novel herpesvirus isolated from adult and subadult white sturgeon Acipenser transmontanus. Dis Aquat Org 22:199-210

Wolf K (1988) Fish viruses and viral diseases. Cornell University Press, Ithaca, NY

Young WS (1992) In situ hybridization with oligodeoxyribonucleotide probes. In: Wilkinson DG (ed) In situ hybridization: a practical approach. Oxford University Press, New York, p 132-144

Submitted: May 18, 2001; Accepted: February 22, 2002 Proofs received from author(s): July 2, 2002 